\title{
OPTIMALISASI PENDIDIKAN ISLAM MELALUI PEMBELAJARAN BERBASIS CARA KERJA OTAK
}

\author{
Eni Purwati \\ Universitas Islam Negeri Sunan Ampel Surabaya, Indonesia \\ E-mail: eni.tarbiyah@gmail.com
}

\begin{abstract}
This article is concerned with the idea of optimalization of Islamic education through brain perform-ancebased learning. As one of the complex part of human body, brain always develops and is able to learn of its-self. The learning process which is appropriate with the work of brain is intended to attract students in order to promote their awareness and have their knowledge stored solidly in their memory. Therefore, the learning process should consider the works and functions of each component of brain: first, reptile serves to regulate the heart and breath; second, lymbic system serves to regulate the system of body immunity, hormon, family need, social stratification, sense of belonging and the realm of emotion; third, neo-cortex serves to regulate the logic, respond something with reason, and control the world of creativity. Teachers should direct students to their human existence that they are the creature of God. This means that what is taught and learnt should be dedicated for individual and social life as a means of worship and service to God.
\end{abstract}

Keywords: Learning; reptile brain; limbic brain; neocortex.

\section{Pendahuluan}

Pendidikan Islam merupakan sendi kokoh dan kuat bagi peradaban umat Islam. Makna dari pendidikan Islam tidak bisa dilepaskan dari keberadaan Islam itu sendiri. Nabi Muhammad pernah bersabda bahwa beliau diturunkan hanya untuk menyempur-nakan kemuliaan akhlak. Di sinilah letak esensi tujuan dari diturunkannya Islam dan dari situlah esensi dari pendidikan Islam. Muhammad 'Aṭ̂yah al-Abrâshî dalam karyanya al-Tarbîyah al-Islâmîyah menyebut- 
kan bahwa tujuan pokok dari pendidikan Islam adalah mendidik budi pekerti dan pembentukan jiwa. ${ }^{1}$

Pengertian di atas mengindikasikan bahwa pengertian dan tujuan pendidikan Islam adalah suatu proses tranformasi dan internalisasi ilmu pengetahuan dan nilai-nilai islami yang dilakukan pendidik kepada anak didik untuk mencapai tujuan terbentuknya individu paripurna sehingga mampu hidup mandiri dan bermanfaat di tengah masyarakat dalam rangka menjalankan perintah Allah sebagai khalifah-Nya di dunia.

Tujuan Pendidikan Islam sejalan dengan tujuan pendidikan nasional di mana pendidikan nasional berfungsi mengembangkan kemampuan dan membentuk watak serta peradaban bangsa yang bermartabat dalam rangka mencerdaskan kehidupan bangsa, bertujuan untuk berkembangnya potensi peserta didik agar menjadi manusia yang beriman dan bertakwa kepada Tuhan Yang Maha Esa, berakhlak mulia, sehat, berilmu, cakap, kreatif, mandiri, dan menjadi warga negara yang demokratis serta bertanggung jawab. ${ }^{2}$

Untuk mencapai tujuan pendidikan Islam yang baik diperlukan upaya-upaya dalam memproses pembelajaran dengan menganalisis cara kerja otak. Karena dengan menggunakan otak (akal) yang diberikan Allah kepada manusia inilah eksistensi manusia sebagai makhluk beradab mampu mengatur dunia sesuai dengan perintahNya.

Otak adalah organ tubuh manusia yang posisinya ditempatkan Allah secara terhormat di bagian atas tubuh manusia dan terlindungi dengan kokoh di bagian dalam tengkorak (batok) kepala. Materi akal atau al-'aql dalam al-Qur'ân tersebut sekira 49 kali dalam 28 surah, yakni 31 kali dalam 19 surah yang diturunkan di Makkah dan 18 kali dalam 9 surah yang diturunkan di Madinah. ${ }^{3}$ Menurut Yûsuf alQarâdâwî penyebutan kata al-'aql dalam bentuk istifhâm inkârî (pertanyaan retoris) — seperti afalâ ta'qilîn — adalah hal yang mencolok dari al-Qur'ân. Itu terjadi karena al-Qur'ân bermaksud menarik perhatian manusia dan bertujuan memotivasi, memberi semangat,

\footnotetext{
1 Muhammad 'Ațiyah al-Abrâshî, al-Tarbiyah al-Islâmîyah (Kairo: Dâr al-Ma'ârif, 1985), 11.

${ }^{2}$ Undang-undang Sistem Pendidikan Nasional, Bab II pasal 3.

3 Taufik Pasiak, Revolusi IQ/EQ/SQ antara Neurosains dan Al-Qur'an (Bandung: PT.Mizan Pustaka, 2004), 200.
} 
dan mendorong manusia untuk menggunakan akalnya. ${ }^{4}$ Firman Allah dalam QS. al-Anfâl [8]: 22 menunjukkan bahwa seburuk manusia di sisi Allah adalah insan yang tidak mau mendengar, menuturkan, dan memahami kebenaran. Kelebihan manusia dengan binatang, tumbuhan, dan manusia adalah terletak pada berfungsi atau tidaknya otak untuk berpikir. ${ }^{5}$

Otak manusia merupakan bagian tubuh paling kompleks yang pernah dikenal di alam semesta. Inilah satu-satunya organ yang senantiasa berkembang, sehingga ia dapat mempelajari dirinya sendiri. Jika dirawat oleh tubuh yang sehat dan lingkungan yang menimbulkan rangsangan, otak itu akan berfungsi secara aktif dan reaktif selama lebih dari seratus tahun. ${ }^{6}$

Kertas kerja ini diharapkan dapat memberikan kontribusi dalam perumusan sistem pendidikan yang inovatif dan aplikatif berbasis tuntutan zaman sesuai dengan perkembangan psikologi anak didik yang sedang mempersiapkan masa depan untuk profesi yang akan dipilihnya. Selain itu diharapkan naskah akademik ini dapat membekali para pendidik atau guru untuk menemukan sistem pembelajaran yang berkualitas, yang dapat membantu anak didik dalam meningkatkan moral yang tinggi.

\section{Cara Kerja Otak}

Pada tahun 1990 Paul Mc. Lean memperkenalkan dan mengembangkan teori "The Triune Brain" yang membagi otak menjadi tiga lapis, yaitu batang atau otak reptil, sistem limbik atau otak mamalia dan neo corteks. ${ }^{7}$ Ketiga bagian itu masing-masing berkembang pada waktu yang berbeda dan mempunyai struktur syaraf tertentu serta mengatur tugasnya masing-masing. ${ }^{8}$ Batang atau otak reptil

\footnotetext{
${ }^{4}$ Yusuf Qardhawi, Al-Qur'an Bicara tentang Akal dan Ilmu Pengetabuan (Jakarta: Gema Insani Press, 1998), 19.

${ }^{5}$ Ibid.

${ }^{6}$ Howard Gardner, Development and Education of the Mind (New York: Basic Books, 1992), 23. Bandingkan Hickman Brynie, Brain Sense: The Science of the Senses and How We Process the World around Us (New York: Amacom, 2010), 44.

7 Paul Mc. Lean adalah kepala dari The Laboratory for Brain Evolution and Behavior pada National Institute for Menthal Health di Amerika Serikat. Taufik Pasiak, Brain Management for Self Improvement (Bandung: Mizan, 2007), 41.

${ }^{8}$ Ibid. Bobby DePorter dan Mike Hernacki sekitar tahun 90-an meluncurkan buku yang sangat terkenal yaitu Quantum Learning: Unleashing The Genius In You yang diterjemahkan oleh Penerbit Kaifa dengan judul Quantum Learning: Membiasakan Belajar Nyaman dan Menyenangkan (1992). Dalam buku tersebut, kedua penulis
} 
adalah komponen kecerdasan terendah manusia. Ia bertanggung jawab terhadap fungsi-fungsi sensor motorik sebagai insting mempertahankan hidup dan pengetahuan tentang realitas fisik yang berasal dari pancaindra. Apabila otak reptil ini dominan, maka seseorang tidak dapat berpikir pada tingkat yang sangat tinggi.

Di sekeliling otak reptil terdapat sistem limbik yang sangat kompleks dan luas. Sistem limbik ini terletak di tengah otak yang fungsinya bersifat emosional dan kognitif. Perasaan, pengalaman yang menyenangkan, memori dan kemampaun belajar dikendalikan oleh sistem limbik ini. Sistem ini juga merupakan panel kontrol yang menggunakan informasi dari pancaindra untuk selanjutnya didistribusikan ke bagian neo-cortex.

Neo-cortex adalah bagian otak yang menyimpan kecerdasan yang lebih tinggi. Penalaran, berpikir secara intelektual, pembuatan keputusan, bahasa, perilaku yang baik, kendali motorik sadar dan penciptaan gagasan (ide) berasal dari pengaturan neo-korteks. Menurut Gardner, kecerdasan majemuk (multiple intelegence) berada pada bagian ini. Bahkan pada bagian ini pula terdapat intuisi yaitu kemampuan untuk menerima atau menyadari informasi yang tidak diterima oleh pancaindra.

\section{Gambar 1:}

Susunan otak "The Triune Brain" dilihat dari samping

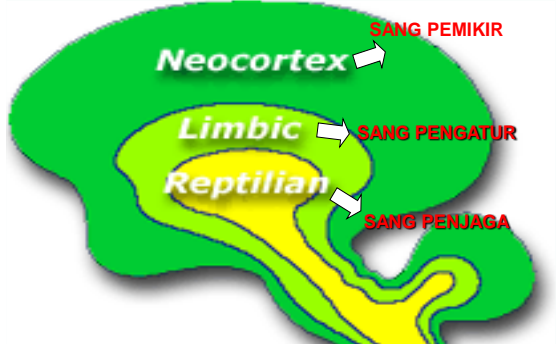

The Triune Brain

ADA 3 OTAK DALAM 1 KEPALA

\begin{tabular}{|l|l|l|}
\hline 1 & $\begin{array}{l}\text { Otak Reptil-Sang Penjaga } \\
\text { - Mengatur fungsi denyut jantung dan pernapasan. } \\
\text { - Melindungi seseorang dari bahaya fisik dengan } \\
\text { pendekatan "lari atau lawan". } \\
\text { - Pada saat otak reptil aktif, orang tidak dapat }\end{array}$ \\
\hline
\end{tabular}

menitikberatkan pada upaya untuk memanfaatkan potensi otak manusia secara optimal. 


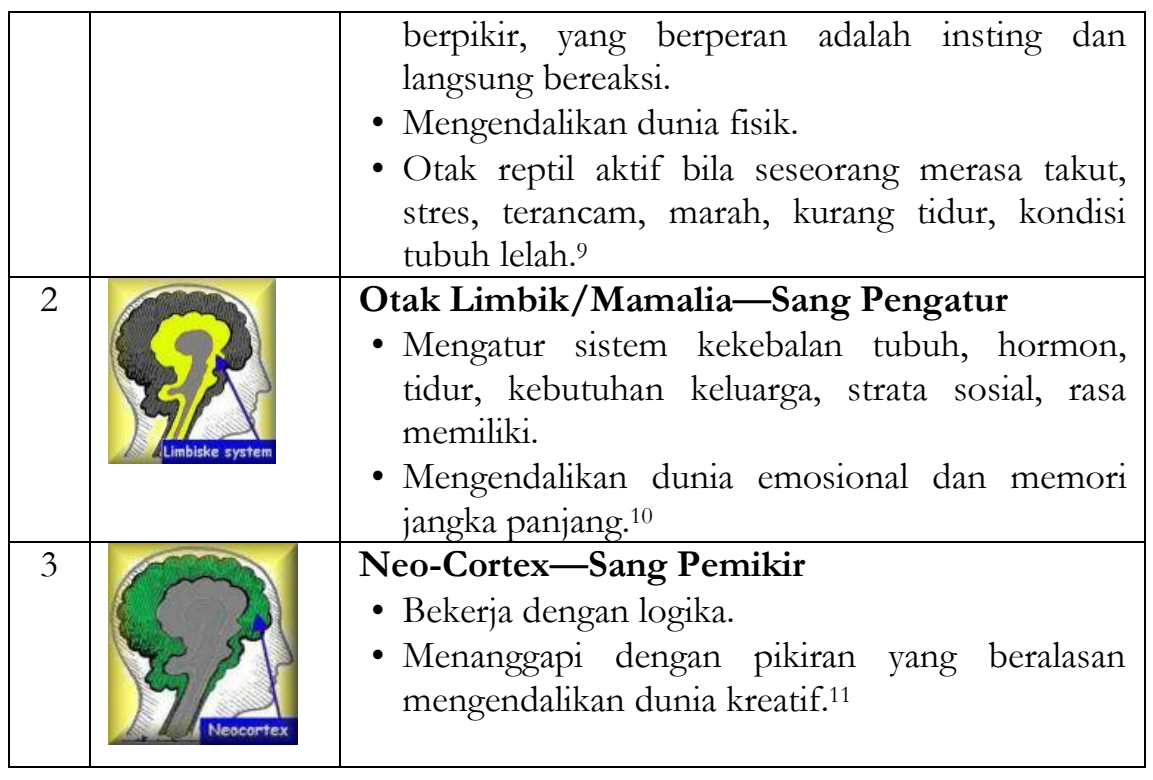

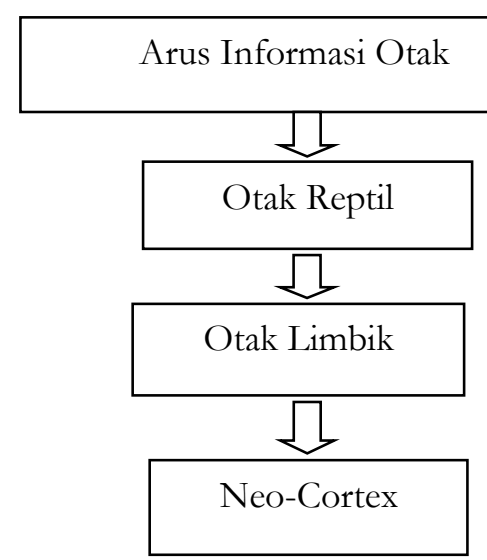

Penelitian menunjukkan bahwa energi informasi bergerak dari dasar otak (otak reptil) melalui pusat emosi (otak limbik/mamalia) terus ke bagian atas neo cortex. Artinya, ketika seseorang mempersiapkan diri untuk belajar, ia harus merasa nyaman secara fisik. Suhu udara, tata cahaya, dan area belajar harus memuaskan otak reptil. Anda harus memulai pembelajaran dengan sikap positif untuk

\footnotetext{
9 Pasiak, Brain Management, 45. Bandingkan Eric Jensen, Brain Based Learning: The New Paradigm of Teaching (California: Corwin Press, 2008), 40.

${ }^{10}$ Ibid., 11.

${ }^{11}$ Ibid.
} 
memuaskan pusat emosi otak (otak mamalia). Ketika dua bagian pertama otak sudah puas otak pemikir dapat bekerja dengan baik.

Dalam ranah pembelajaran, otak reptil_sang penjaga merupakan kemampuan guru mengatur lingkungan dan suasana kelas agar tampak indah, asri, dan nyaman. Otak limbik/mamalia-sang pengatur merupakan kemampuan guru untuk membangun emosi positif dan konsep diri peserta didik, terutama pada materi character building. Sedangkan neo-cortex — sang pemikir, merupakan kemampuan guru dalam mengolah teaching methodology, termasuk gaya mengajar multiple intelligences peserta didik dikaitkan dengan penguasaan materi yang telah diterima oleh otak limbic. Apabila informasi yang masuk dalam neo cortex berisi pesan-pesan yang berhubungan dengan moral dan makna hidup, maka akan muncullah kecerdasan eksistensial/spiritual. Nampaknya inilah yang dimaksud God Spot (Titik Tuhan) yang ditemukan oleh Persinger dan Ramachandran yang kemudian ditindaklanjuti oleh Danah Zohar dan Ian Marshal, mengungkapkan bahwa pada diri setiap manusia, apapun agama dan rasnya Tuhan telah menganugerahi suatu potensi kecerdasan spiritual. ${ }^{12}$

Temuan God Spot ini semakin membuktikan kebenaran al-Qur'ân sebagai mu'jizat abadi tentang fitrah beragama (dalam arti mengakui adanya kekuatan spiritual Tuhan) yang secara inheren sudah given diberikan Allah kepada setiap anak manusia yang lahir, siapapun dia dengan latar belakang budaya, ras dan agama apapun, sebagaimana yang diinformasikan dalam QS al-A'râf [7]: 172. Adanya God Spot dalam otak dapat dilihat dalam gambar berikut.

Gambar 2:

God Spot dalam Otak

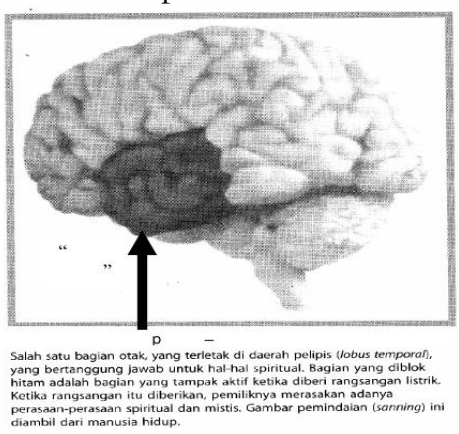

${ }^{12}$ Danah Zohar dan Ian Marshall, Project SQ: Spiritual Intelligence the Ultimate Intelligence (London: Bloomsbury Publishing, 2000), 3-5. 
Taufik Pasiak mengatakan bahwa sekalipun masih berupa penelitian kasar yang perlu diperdalam lagi, sekurangnya terdapat empat bukti penelitian yang memperkuat dugaan adanya potensi spiritualitas dan hardware Tuhan dalam otak manusia, yaitu:

1) Osilasi $40 \mathrm{~Hz}$ yang ditemukan oleh Denis Pare dan Rodolfo Llinas, dan dikembangkan oleh Danah Zohar dengan teori kecerdasan spiritualnya.

2) Alam bawah sadar kognitif yang ditemukan oleh Joseph deLoux, dan dikembangkan oleh Daniel Goleman dengan teori kecerdasan emosi, serta Robert Cooper dengan teori suara hati.

3) God Spot dalam daerah temporal (sekitar pelipis) yang ditemukan oleh Michael Persinger dan Vilyanus Ramachandran, dan

4) Somatic Marker (penanda somatik) dari Antonio Damasio. Dari berbagai hasil penelitian mutakhir yang dilakukan para ahli, disimpulkan bahwa otak manusia mempunyai tiga fungsi yaitu: 1) fungsi kognisi-rasional logis, 2) fungsi emosional-intuitif, dan 3) fungsi spiritual. ${ }^{13}$

Menurut Roger W. Sperry, otak juga dibagi menjadi dua belahan penting, yaitu otak kiri dan otak kanan, yang masing-masing bertanggung jawab atas cara berpikir yang berbeda-beda, walau penyilangan antara dua bagian itu pun tetap ada. Otak kiri bersifat logis, sekuensial, linier dan rasional. Otak kanan bersifat acak, tidak teratur, intuitif, dan holistik. ${ }^{14}$ Adanya dua belahan otak dapat dilihat dalam gambar berikut.

\footnotetext{
13 Pasiak, Revolusi IQ/EQ/SQ, 275.

${ }^{14}$ L. Michael Hall dan Bob G. Bodenhamer, The User's Manual for The Brain (British Library: Crown House Publishing Limited, 1999), 103. Dalam buku ini dijelaskan bahwa temuan adanya belahan otak kiri dan kanan, bermula dari penemuan hebat Roger W. Sperry di tahun 1960. Awal mulanya, Sperry melakukan penelitian terhadap orang yang mengalami sakit epilepsi di mana sambungan antara otak kiri dan kanan (corpus collosum) yang diduga bahwa dengan pemotongan corpus calosum ini mampu meredakan penyakit epilepsi tersebut. Tetapi pemotongan sambungan tersebut mempunyai efek di mana otak kiri dan kanannya tidak dapat bekerja sama, misalkan ia dapat melihat seekor simpanse tetapi tidak dapat menyebutkan namanya. Berkat penelitian tersebut Sperry mendapat anugerah hadiah nobel di tahun 1981.
} 
Gambar 3:

Susunan otak kiri-otak kanan dilihat dari belakang

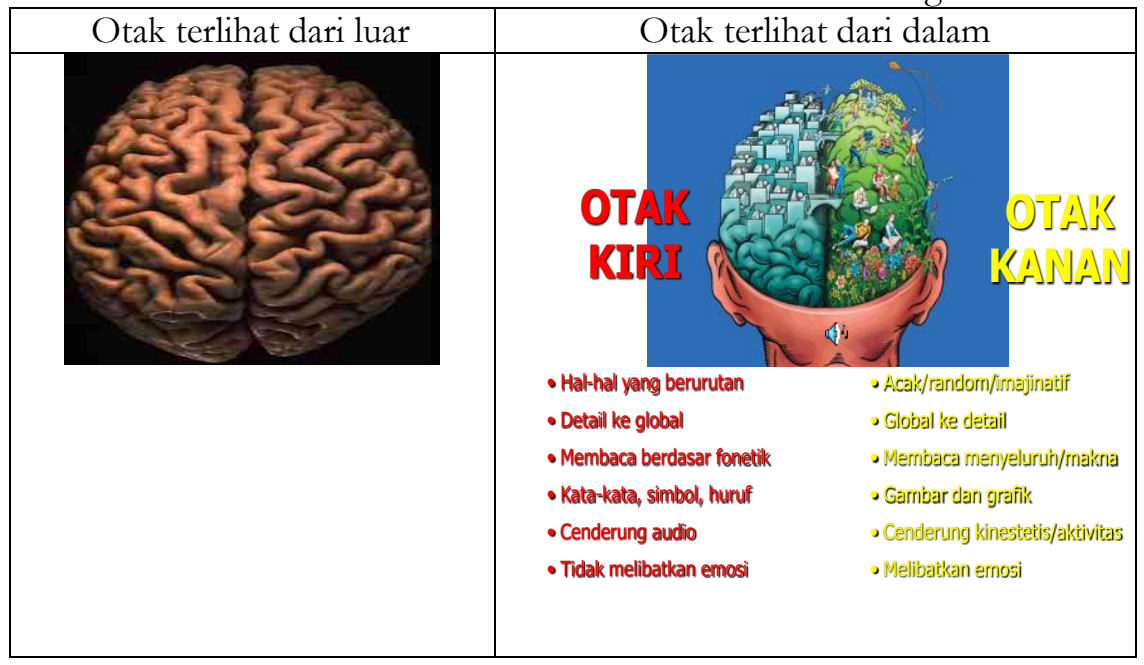

Fenomena tentang otak dilihat dari samping dan dari belakang yang berbeda tersebut, ibarat dua sisi dari mata uang logam, sulit dipisahkan baik susunan sel maupun fungsinya, ada keterikatan dan keterkaitan kuat di antara keduanya. Dengan demikian, dalam proses pemberian informasi pada peserta didik, harus menggunakan bolistic brain, artinya cara penyampaian informasi tersebut harus merupakan konsumsi otak kanan dan otak kiri secara seimbang.

Hubungan antara otak kiri dan otak kanan dengan memori otak dalam pengelolaan informasi adalah, bahwa informasi yang masuk ke otak kiri, bersifat sementara dalam jangka pendek, sehingga ingatan mudah terhapus dan mudah lupa. Informasi yang masuk ke otak kanan bersifat tahan lama, tidak mudah terhapus dan diingat seterusnya. $^{15}$

${ }^{15}$ Ibid. Bandingkan Tony Buzan, The Power of Creative Intelligence: 10 Ways to Tap into your Creative Genius (Thorsons: Harper Collins Publisher, 2001), 78. 
Gambar 4:

Hubungan Otak Kiri dan Otak Kanan dalam Pembelajaran

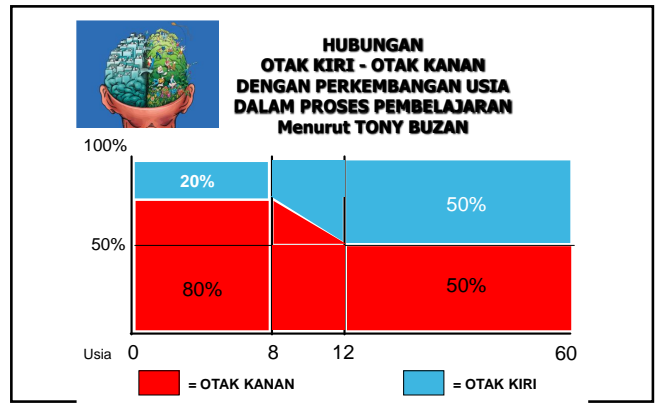

Kedua bagian belahan otak itu teramat penting dalam kecerdasan dan tingkat kesuksesan. Seseorang yang mampu memanfaatkan kedua belahan otak ini secara proporsional akan cenderung seimbang dalam setiap aspek kehidupannya. Tentunya dalam kegiatan pembelajaran yang mengacu dan memperhatikan kedua belahan otak ini juga akan menentukan sejauhmana tingkat kecerdasan yang dapat diraih oleh peserta didik.

Dalam proses berpikir, informasi yang diterima melalui panca indera ditangkap oleh sel saraf yang disebut neuron. Sel Otak (neuron) bekerja membentuk jaringan koneksi (sinapsis), di mana neurotransmitter sangat berperan membawa informasi antarjaringan, membuat otak seseorang berfungsi optimal (berpikir) dan menunjukkan bagaimana akal berfungsi. Interaksi antar sel ini dapat menimbulkan miliaran komunikasi perdetik, sebelum adanya penetapan kesimpulan atau pengambilan keputusan terhadap satu informasi yang diterima. Proses komunikasi atau berpikir ini menimbulkan gelombang di otak (getaran sel saraf karena tersentuh muatan listrik dari ujung sel saraf) yang terdeteksi melalui EEG (Elektro Ensefalo Grafi), yaitu: ${ }^{16}$

\begin{tabular}{|c|c|c|}
\hline 1 & Naw & $\begin{array}{l}\text { Beta }(12-25 \mathrm{~Hz}) \\
\text { Kondisi seseorang sadar, melakukan aktivitas } \\
\text { sehari-hari yang berkonsentrasi tinggi, } \\
\text { melakukan debat, berolahraga atau melakukan } \\
\text { proyek yang rumit. }\end{array}$ \\
\hline
\end{tabular}

${ }^{16}$ Eric Jensen, Teaching with the Brain in Mind, 2nd Edition (Virginia: Association for Supervision and Curriculum Development Alexandria, 2005), 89-95. Bandingkan Karl Albrecht, The Power Minds at Work: Organizational Intelligence in Action (New York: Amacom, 2002), 114-117. 


\begin{tabular}{|c|l|l|}
\hline 2 & $\begin{array}{l}\text { Alfa (8-12 Hz) } \\
\text { Seseorang dalam keadaan rileks tetapi waspada, } \\
\text { misal membaca, menulis, melihat, memikirkan } \\
\text { jalan keluar suatu masalah. } \\
\text { Saat yang paling tepat untuk belajar, karena } \\
\text { neuron berada dalam suatu harmoni, } \\
\text { melakukan tembakan impuls listrik bersamaan } \\
\text { dan beristirahat juga bersamaan. Hal ini } \\
\text { menunjukkan terjadi efesiensi pada jalur saraf. }\end{array}$ \\
\hline 3 & $\begin{array}{l}\text { Theta (4-8 Hz) } \\
\text { Seseorang dalam keadaan sangat rileks, kondisi } \\
\text { meditatif, ide-ide kreatif muncul. }\end{array}$ \\
\hline
\end{tabular}

Gambar 5: Gelombang Otak

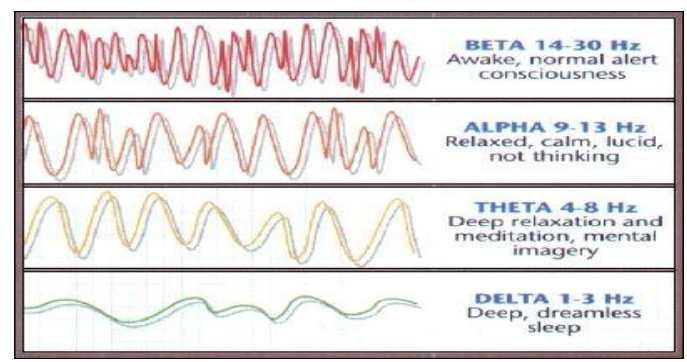

Untuk masuk dalam kondisi alpha pembelajaran dapat dimulai dengan kegiatan ice breaking, fun story, brain game, atau musik.

Bahan bakar otak seseorang terdiri dari oksigen, glukosa, dan air, maka harus banyak minum air dalam proses belajar. Menghindari makan terlalu kenyang sebelum proses belajar, sebab banyak darah yang terkonsentrasi ke proses pencernaan, akibatnya suplai darah ke otak kurang dan membuat seseorang mengantuk. Juga jumlah karbohidrat yang terlalu banyak akan menaikkan kadar gula/glukosa dalam darah, membuat seseorang mengantuk. ${ }^{17}$

Kecepatan otak dalam belajar dapat dijelaskan bahwa potensi otak secara audio mampu memproses 30 ribu bit data perdetik. Secara visual mampu memproses 100 juta bit data perdetik. Secara kinestetis

17 Albrecht, The Power Minds at Work, 116. 
(indera raba dan sentuh) mampu memproses 300 juta bit data perdetik. Total $=400.030 .000$ bit data perdetik.

Rata-rata otak seseorang yang terpakai menurut Nick Herbet dalam buku The Elemental Mind, menyatakan bahwa secara sadar seseorang hanya memproses $15-50$ bit data perdetik. Betapa seseorang sangat amat teramat kurang sekali menggunakan kemampuan otak seseorang.

\section{Optimalisasi Pembelajaran Melalui Cara Kerja Otak}

Pembelajaran dengan menggunakan cara kerja otak ini sejalan dengan konsep pendidikan Islam, bahwa manusia diciptakan oleh Allah paling sempurna di antara makhluk lain, karena manusia diberi otak. Otak adalah sumber kekuatan yang sangat dahsyat apabila manusia mampu menggunakan dengan sebaik-baiknya.

Pengelolaan pembelajaran berbasis cara kerja otak sangat memperhatikan belajar cara belajar, yaitu proses pembelajaran agar peserta didik tertarik, berhasil dalam belajar dalam waktu yang relatif cepat, informasi/ilmu yang diperoleh dapat menggugah kesadaran dan tersimpan dalam ingatan yang kuat (long term memory).

Dalam upaya mengubah paradigma pembelajaran sehingga dapat memberdayakan otak secara optimal. Eric Jensen menawarkan sebuah konsep dalam menciptakan pembelajaran dengan orientasi pada upaya pemberdayaan otak peserta didik. ${ }^{18}$ Menurutnya ada tiga strategi berkaitan dengan cara mengimplementasikan pembelajaran berbasis kemampuan otak, yaitu:

1. Menciptakan suasana atau lingkungan yang mampu merangsang kemampuan berpikir peserta didik. Strategi ini bisa dilakukan terutama pada saat guru memberikan soal-soal untuk mengevaluasi materi pelajaran. Soal-soal yang diberikan harus dikemas seatraktif mungkin sehingga kemampuan berpikir peserta didik lebih optimal, seperti melalui teka-teki, simulasi, permainan dan sebagainya.

2. Menghadirkan peserta didik dalam lingkungan pembelajaran yang cukup menyenangkan. Guru tidak hanya memanfaatkan ruangan kelas untuk belajar peserta didik, tetapi juga tempat-tempat lainnya, seperti di taman, di lapangan bahkan di luar sekolah. Guru harus menghindarkan situasi pembelajaran yang dapat membuat peserta didik merasa tidak nyaman, mudah bosan atau tidak senang terlibat di dalamnya. Strategi pembelajaran yang

${ }^{18}$ Jensen, Brain Based Learning, 188-192. 
digunakan lebih menekankan pada diskusi kelompok yang diselingi permainan menarik serta variasi lain yang kiranya dapat menciptakan suasana yang menggairahkan peserta didik dalam belajar.

3. Membuat suasana pembelajaran yang aktif dan bermakna bagi peserta didik. Pembelajaran yang aktif dan bermakna hanya dapat dilakukan apabila peserta didik secara fisik maupun psikis dapat beraktivitas secara optimal. Strategi pembelajaran yang digunakan dikemas sedemikian rupa sehingga peserta didik terlibat secara atraktif dan interaktif, melalui model pembelajaran yang bersifat demonstrasi. ${ }^{19}$

Apa yang dikemukakan Eric Jensen di atas merupakan upaya konkret dalam meningkatkan kualitas pembelajaran. Namun, kunci keberhasilan itu semua terletak pada kemauan dan kemampuan guru untuk mereformasi cara dan strategi pembelajarannya serta berani untuk menggeser paradigma berpikirnya, sehingga lebih bersifat praksis ketimbang teoretis. Hal tersebut dapat disebut accelerated learning yang dapat diskemakan berikut.

Gambar 6:

Skema Accelerated Learning

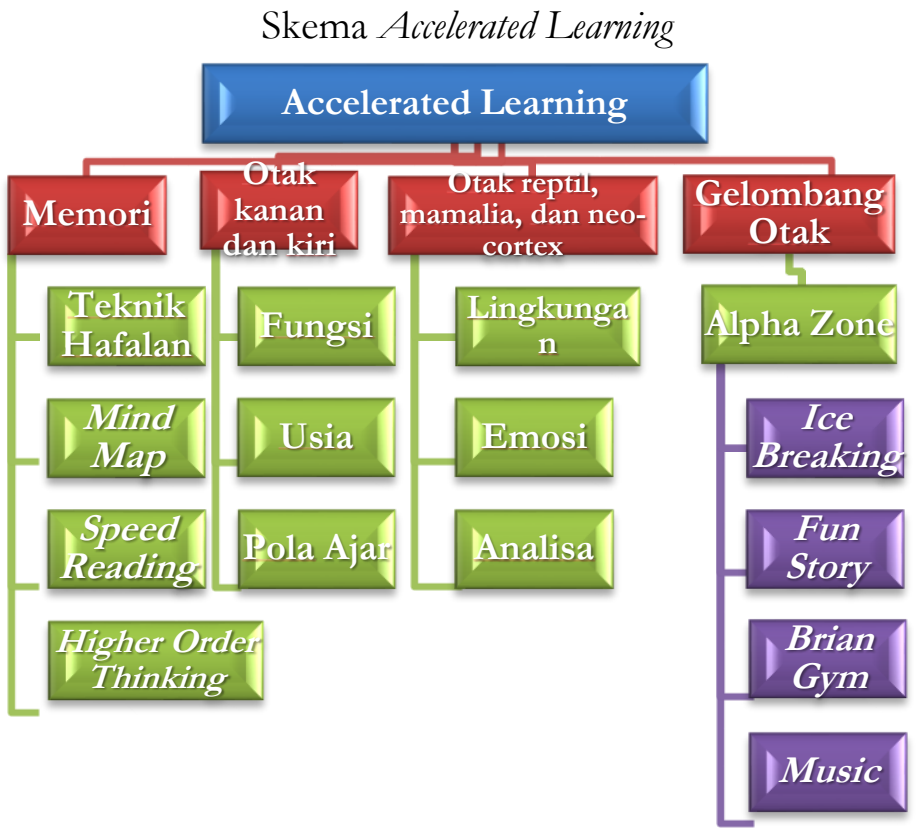

Langkah-langkah kegiatan pembelajaran berbasis cara kerja otak.

${ }^{19} \mathrm{Ibid}$ 
Pertama, apersepsi. Berhasilnya sebuah pembelajaran tergantung pada menit-menit pertama membuat peserta didik penasaran. Agar terbangun koneksi sel dan neuron dalam otak kegiatan apersepsi berupa pemberian pengalaman dengan mengondisikan; kesiapan otak menerima informasi, mengeluarkan informasi dari dalam otak, dan memberi rangsangan baru dalam otak. Kegiatan pembelajaran dalam apersepsi:

1. Alpha Zone. Kesiapan otak menerima informasi; ice breaking, fun story, brain game, dan music.

2. Warmer. Mengeluarkan informasi dari dalam otak; berkaitan dengan pengulangan materi yang telah dibelajarkan sebelumnya.

3. Pre Teach. Berkaitan dengan informasi pendahuluan.

4. Scene setting. Mengeluarkan informasi dari dalam otak dan memberi rangsangan baru dalam otak; berkaitan dengan aktivitas pembelajaran.

Pola-pola scene setting dapat dikembangkan melalui:

(a) Visualization Demo

- Demo visual dengan menggunakan teaching aids yang terkait dengan materi belajar.

- Demo visual dapat melibatkan peserta didik.

- Demo visual berfungsi untuk pemahaman materi dalam memori jangka panjang.

(b) Simulation Demo

- Demo simulasi adalah aktivitas awal dengan melibatkan peserta didik dalam sebuah simulasi kondisi yang terjadi sehari-hari.

- Pada simulasi demo diharapkan para peserta didik dapat merasakan kaitan antara sebuah kondisi yang disimulasikan dengan materi belajar yang akan diajarkan.

(c) Pantomim

- Pantomim yang dilakukan guru akan membangkitkan semangat peserta didik untuk mencari tahu apa maksud pelajaran tersebut.

- Pantomim juga dapat dilakukan oleh peserta didik atas arahan guru, dan peserta didik yang lain mengamati.

(d) Mendatangkan Tokoh

- Awal pembelajaran dengan mendatangkan tokoh akan sangat menarik peserta didik untuk mengikuti kelanjutan dari pelajaran tersebut. 
- Tokoh tersebut harus sebentar saja kehadirannya dalam kelas. ${ }^{20}$

Fungsi scene setting adalah untuk pemberian pengalaman belajar sebelum masuk ke materi inti, membangun konsep pembelajaran yang akan diberikan, memantik penasaran peserta didik, dan pereduksi perintah. Alur berpikir dalam menggunakan scene setting, berawal dari sumber ide, berkaitan dengan jenis aktivitas, berkaitan dengan indikator hasil belajar, dan berkaitan dengan kompetensi dasar.

Sumber ide scene setting harus bermakna, dan tersimpan dalam arsip memori jangka panjang. Sumber scene setting dapat beraneka ragam;

(a) Keselamatan Hidup

- Berkaitan dengan keselamatan hidup seseorang atau makhluk lain.

- Akan lebih berkesan apabila yang terancam pada lingkaran terdekat pada diri peserta didik dan keluarganya.

- Contoh yang banyak digunakan adalah bencana alam, penyakit, kecelakaan dan lain-lain.

(b) Kegunaan/Manfaat

- Aktivitas yang akan diajarkan berkaitan dengan adanya manfaat yang akan di dapat peserta didik pada saat aktivitas itu dilakukan.

- Manfaat tersebut akan lebih baik dapat dirasakan langsung oleh peserta didik pada saat selesai melakukan aktivitas.

- Contoh yang banyak digunakan adalah kegunaan dari suatu alat, atau manfaat aktivitas untuk tubuh dan pengetahuan.

(c) Sebab Akibat

- Aktivitas yang akan diajarkan berkaitan dengan adanya akibat yang akan terjadi apabila aktivitas tersebut dikerjakan.

- Akibat yang terjadi lebih baik bersifat "ekstrem"—-sangat menyentuh dan berpengaruh kepada peserta didik.

- Contoh yang banyak digunakan adalah menceritakan akibat atau dampak yang akan terjadi.

(d) Penyampaian Informasi/Berita

- Aktivitas yang akan diajarkan berkaitan dengan berita atau informasi yang "up to date".

20 Thomas Armstrong, Multiple Intelligences in the Classroom (Alexandria, VA: Association for Supervision and Curriculum Development, 1992), 87-89. 
- Berita tersebut dapat dapat dibacakan atau diceritakan oleh guru.

- Contohnya dengan membawa kliping koran atau majalah tentang berita yang terkait dengan materi belajar.

(e) Cerita Imajinatif

- Sebelum melakukan aktivitas pembelajaran, diawali dengan cerita khayalan yang menarik minat peserta didik untuk masuk ke materi belajar.

- Cerita tersebut dapat berupa cerita dari film-film fiksi atau guru mengarang sendiri.

- Biasanya cerita imajinatif ini sangat disukai oleh para peserta didik usia golden age (usia emas).

(f) Pertanyaan

- Sebelum melakukan aktivitas pembelajaran, diawali dengan beberapa pertanyaan yang memancing peserta didik untuk membawa kepada materi pembelajaran.

- Cara guru bertanya pada awal belajar ini dapat bervariasi model dan caranya. Pertanyaan dapat merupakan pertanyaan berantai.

- Biasanya akan berhasil apabila ada penghargaan yang akan diberikan kepada peserta didik apabila pertanyaan tersebut dapat dijawab.

(g) Film

- Aktivitas belajar di awali dengan film, yang mana peserta didik tidak diberitahu judul dan maksud film tersebut.

- Biasanya guru membagi beberapa kelompok peserta didik untuk memberi komentar setelah film diputar.

- Jenis film dapat beragam sesuai dengan materi belajar.

Kedua, strategi menyusun aktivitas belajar dengan multiple intelligences. Aktivitas pembelajaran yang merujuk pada indikator hasil belajar yang sudah ditentukan dan gaya mengajar guru menitikkuatkan pada gaya belajar peserta didik-sebagaimana dijelaskan di atas-dilaksanakan dengan langkah-langkah, antara lain: a). Membatasi waktu guru dalam melakukan presentasi (30\%), melimpahkan waktu terbanyak (70\%) untuk aktivitas peserta didik. Dengan aktivitas tersebut, secara otomatis peserta didik akan belajar; dan, b). Menggunakan modalitas belajar yang tertinggi, yaitu dengan modalitas kinestetis dan visual dengan akses informasi melihat, mengucapkan, dan melakukan. Menurut Venon Magnesen dari Texas 
University, otak manusia lebih cepat menangkap informasi yang berasal dari modalitas visual yang bergerak. Berikut detail laporan penelitiannya. ${ }^{21}$

Gambar 7:

Persentase Modalitas Pembelajaran

\begin{tabular}{|c|l|c|}
\hline No & \multicolumn{1}{|c|}{ Aksi } & Persentase \\
\hline 1 & Membaca & $20 \%$ \\
\hline 2 & Mendengar & $30 \%$ \\
\hline 3 & Melihat & $40 \%$ \\
\hline 4 & Mengucapkan & $50 \%$ \\
\hline 5 & Melakukan & $60 \%$ \\
\hline 6 & Melihat, Mengucapkan, dan Melakukan & $90 \%$ \\
\hline
\end{tabular}

Ketiga, mengaitkan materi yang diajarkan dengan aplikasi dalam kehidupan sehari-hari yang mengandung keselamatan hidup. Keempat, menyampaikan materi kepada peserta didik dengan melibatkan emosinya, dan menghindarkan pemberian materi secara hambar dan membosankan. Dan kelima, pembelajaran dengan melibatkan partisipasi peserta didik untuk menghasilkan manfaat yang nyata dan dapat langsung dirasakan oleh orang lain, sehingga peserta didik merasa mempunyai kemampuan untuk menunjukkan eksistensi dirinya.

Dari uraian di atas dapat disimpulkan bahwa, belajar cara belajar adalah aktivitas dalam proses belajar harus terkait dengan konsep holistic activities, yaitu dengan menggunakan kesadaran, tubuh, perasaan, pikiran, dan ingatan. Dapat digambarkan sebagai berikut.

Gambar 8:

Holistic Activities dalam Pembelajaran ${ }^{22}$

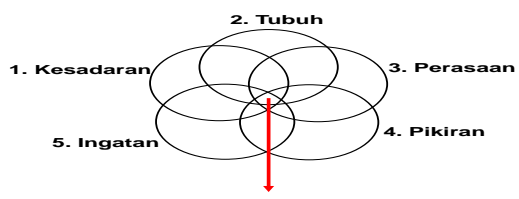

Holistic Activities

Kesadaran akan menciptakan kebutuhan akan belajar; menumbuhkan minat belajar; dan mempunyai peranan apersepsi sangat besar (scene setting, warmer, pre-teach, dan alpha zone). Adapun tubub adalah alat

${ }^{21}$ Laporan Penelitian Venon Magnesen dari Texas University tentang penggunaan modalitas pembelajaran, lihat Munif Chatib, Sekolabnya Manusia (Bandung: PT Mizan Pustaka, 2009), 136-137.

22 Jensen, Brain Based Learning, 219. 
untuk memproses belajar; kondisi fisik peserta didik, guru dan lingkungan belajar sangat menentukan; dan peranan otak reptil sangat besar. Sedangkan perasaan adalah proses belajar harus mengandung rasa penasaran dan muatan emosi; dan ia mempunyai peranan otak mamalia sangat besar. Adapun pikiran, bahwa proses belajar adalah tantangan mengetahui, memahami, mengamati, menganalisa, sintesa dan evaluasi; pun ia mempunyai peranan sebagai otak cortex dengan sangat besar. Sedangkan yang terakhir adalah ingatan sebagai proses belajar masuk memori jangka panjang; ia berkait erat dengan aktivitas yang mengandung survival, emotional, relevant, dan rehearsal; dan ia berperan dalam bawah sadar.

Dalam konsep The Whole Brain, Ned Herrmann membagi otak dalam empat kuadran, yang dapat digambarkan sebagai berikut.

Gambar 9:

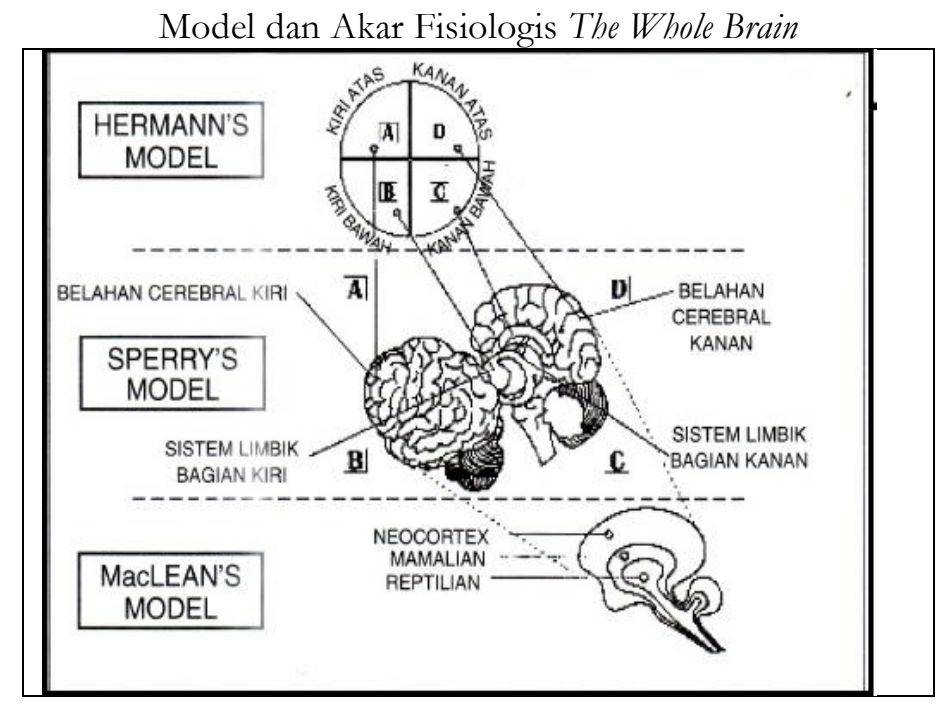

Penjelasan gambar empat kuadran otak menurut Ned Herrmann adalah: kuadran A, yaitu bagian otak kiri atas disebut sebagai analis (analyzer) dengan dominasi terhadap berpikir logis, analisis fakta, memproses angka-angka. Kuadran B yaitu bagian otak kiri bawah disebut sebagai organisator (organizer) dengan dominasi terhadap perencanaan, mengorganisir hal-hal teknis, dan segala sesuatu dengan rinci. Kuadran $\mathrm{C}$ yaitu bagian otak kanan bawah, disebut Personalis (personalizer) dengan dominasi terhadap hubungan interpersonal, intuisi, dan ekspresif. Kuadran D yaitu bagian otak kanan atas disebut sebagai strategis/visualis (strategizer/visualizer) 
dengan dominasi terhadap konsep-konsep, imajinasi, gagasangagasan strategis. Secara detail dapat dilihat dalam tabel berikut:

Tabel 1:

Empat Kuadran Otak

\begin{tabular}{|l|l|l|}
\hline \multicolumn{1}{|c|}{ Letak Otak } & \multicolumn{1}{c|}{ Gaya Berpikir } & \multicolumn{1}{c|}{ Aplikasi } \\
\hline $\begin{array}{l}\text { Kiri Atas } \\
\text { (Analytic Thinking) }\end{array}$ & $\begin{array}{l}\text { Logis, Analitis, } \\
\text { Faktual }\end{array}$ & $\begin{array}{l}\text { Logika, Analitikal, } \\
\text { Matematik, Pengukuran, } \\
\text { Teknik, Saintifik }\end{array}$ \\
\hline $\begin{array}{l}\text { Kiri Bawah } \\
\text { (Implementation } \\
\text { Thinking) }\end{array}$ & $\begin{array}{l}\text { Organisasi, } \\
\text { Sekuensial, } \\
\text { Perencanaan, Rinci }\end{array}$ & $\begin{array}{l}\text { Pengontrolan, } \\
\text { Konservatif, } \\
\text { Organisasional, } \\
\text { Administratif }\end{array}$ \\
\hline $\begin{array}{l}\text { Kanan Atas } \\
\text { (Future Thinking) }\end{array}$ & $\begin{array}{l}\text { Holistik, Intuitif, } \\
\text { Integrasi, Sintesis }\end{array}$ & $\begin{array}{l}\text { Imajinasi, Artistik, } \\
\text { Sintesis, Non- linier }\end{array}$ \\
\hline $\begin{array}{l}\text { Kanan Bawah } \\
\text { Social Thinking) }\end{array}$ & $\begin{array}{l}\text { Interpersonal, Sosial, } \\
\text { Kinestetis, Emosi }\end{array}$ & $\begin{array}{l}\text { Hubungan Sosial, } \\
\text { Emosional, } \\
\text { Spiritualitas. }\end{array}$ \\
\hline
\end{tabular}

Dari hasil penelitian profil dominasi otak tersebut dapat dideskripsikan bagaimana profil otak seseorang merefleksikan profil potensi dan perilakunya, sebagai berikut:

1. Setiap orang paling tidak memiliki satu kecenderungan utama.

2. Lebih dari $90 \%$ manusia merupakan multi-dominan. Artinya memiliki paling sedikit dua dominasi otak yang kuat.

3. Dominasi otak ataupun penghindaran (ketaksukaan) pada seseorang sama pentingnya.

4. Individu dengan profil dominasi yang berbeda cenderung berperilaku tertentu/spesifik dan dapat diduga dalam kaitan misalnya dengan waktu, kreativitas, cara berpakaian, menyelesaikan masalah, menggunakan intuisinya, dan juga dalam melihat uang.

5. Individu dengan profil dominasi yang sama cenderung lebih mudah berkomunikasi satu sama lain walaupun menghadapi batasan/perbedaan budaya.

6. Orang-orang memiliki profil dominasi yang sama cenderung bergabung dalam satu kelompok.

7. Masalah-masalah dalam kelompok dapat lebih mudah diselesaikan bila mereka mengerti profil dominasinya satu sama lain. 
8. Banyak norma profesi yang tidak dibatasi oleh perbedaan budaya karena sifat pekerjaannya sama. ${ }^{23}$

Walter McKenzie-dalam bukunya Multiple Intelligences and Instructional Technology-sependapat dengan Gardner bahwa dalam bagian otak terdapat kecerdasan eksistensial sebagai salah satu bagian dari kecerdasan majemuk. Bahkan McKenzie telah merumuskan berbagai strategi, media, dan teknologi yang dapat digunakan untuk mengembangkan kecerdasan eksistensial tersebut. ${ }^{24}$

Pembelajaran berbasis teori kecerdasan majemuk menurut McKenzie dapat digambarkan sebagai berikut.

Gambar 10:

Pembelajaran Berbasis 9 Kecerdasan Majemuk

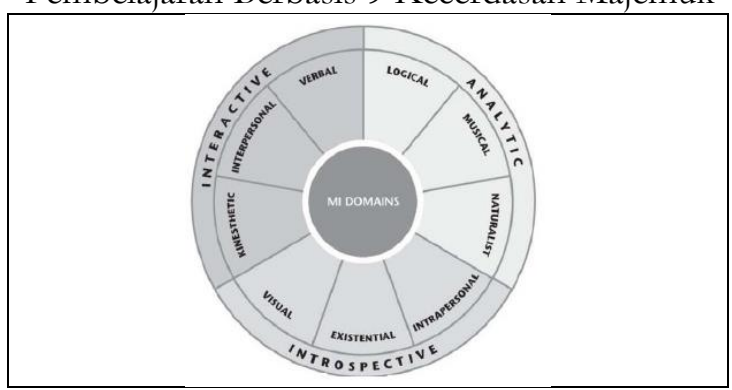

Kecerdasan menurut McKenzie dikelompokkan ke dalam tiga wilayah, atau domain, yakni interaktif, analitik, dan introspektif. ${ }^{25}$ Ketiga domain ini dimaksudkan untuk menyelaraskan kecerdasan dengan peserta didik yang ada kemudian diamati oleh guru secara rutin di dalam ruang kelas.

Domain Interaktif. Domain ini terdiri atas kecerdasan verbal, interpersonal, dan kinestetik. Peserta didik biasanya menggunakan kecerdasan ini untuk mengekspresikan diri dan mengeksplorasi lingkungan mereka. Dimasukannya ciri masing-masing dari ketiga kecerdasan ini sebagai interaktif karena meskipun kecerdasan tersebut dapat dirangsang melalui kegiatan pasif, mereka biasanya mengundang dan mendorong interaksi untuk mencapai pemahaman. Bahkan jika peserta didik menyelesaikan tugas secara individual, mereka harus mempertimbangkan orang lain melalui cara mereka menulis, menciptakan sesuatu, membangun, dan menggunakan pendekatan untuk

\footnotetext{
23 Pasiak, Revolusi IQ/EQ/SQ, 279-280.

${ }^{24}$ Walter McKenzie, Multiple Intelligences and Instructional Technology (Washington DC: International Society for Technology Education, 2005).

${ }^{25}$ McKenzie, Multiple Intelligences, 119.
} 
sampai pada kesimpulan. Kecerdasan interaktif diperoleh melalui proses sosial yang terbangun secara alamiah.

Domain Analitik. Domain ini terdiri atas kecerdasan musik, logis, dan kecerdasan naturalis yang digunakan oleh peserta didik dalam menganalisis data dan pengetahuan. Ketiga ciri kecerdasan ini disebut sebagai kecerdasan analitik karena meskipun dapat memiliki komponen sosial atau introspektif, kecerdasan tersebut kebanyakan dapat digunakan untuk menganalisis dan menggabungkan data ke dalam skema yang sudah ada. Kecerdasan analitis pada dasarnya merupakan proses heuristik alamiah.

Domain introspektif. Domain ini terdiri atas kecerdasan eksistensial, intrapersonal, dan visual. Kecerdasan ini sangat jelas memiliki komponen afektif. Ketiga kecerdasan ini diklasifikasikan sebagai introspektif karena memerlukan keterlibatan peserta didik untuk melihat sesuatu lebih dalam dari sekadar memandang melainkan harus mampu membuat hubungan emosional antara yang mereka pelajari dengan pengalaman masa lalu. Di samping itu, peserta didik juga harus mempunyai keyakinan terhadap adanya perubahan yang terjadi dalam pembelajaran baru. Kecerdasan introspektif dapat dicapai melalui proses afektif secara alamiah.

\section{Optimalisasi Pendidikan Islam Melalui Pembelajaran Berbasis Cara Kerja Otak}

Untuk mendapatkan gambaran jelas tentang optimalisasi pendidikan Islam melalui pembelajaran berbasis cara kerja otak, berikut dipaparkan contoh aplikasi dalam pembelajaran al-Qur'ân dengan tema "Kepedulian sosial" untuk MTs kelas VIII semester gasal. Materi QS. al-Kawthar [108] dan QS. al-Mâ'ûn [107] waktu 2 x pertemuan@120 menit dengan tujuan pembelajaran antara lain: pertama, peserta didik mampu memahami isi kandungan QS al-Kauthar dan al-Mâ'ûn tentang kepedulian sosial, dan kedua, peserta didik mampu memahami keterkaitan isi kandungan QS. al-Kawthar [108] dan QS. al-Mâ'ûn [107] tentang kepedulian sosial dalam fenomena kehidupan sehari-hari.

Aktivitas Pembelajaran Pertemuan I

\begin{tabular}{l|l} 
Strategi & Kegiatan \\
\hline
\end{tabular}




\begin{tabular}{|c|c|}
\hline Alpha Zone & $\begin{array}{l}\text { Salam pembuka } \\
\text { Mengecek kondisi peserta didik } \\
\text { Fun Story bernyanyi bersama "Sepohon Kayu" }\end{array}$ \\
\hline Scene Setting & Mengamati cuplikan film “Air Mata Ibu” melalui LCD \\
\hline Metode & $\begin{array}{l}\text { Melakukan drill mufradât dengan suara keras dan fasih } \\
\text { sambil menunjukkan tulisan disertai gambar dalam } \\
\text { power point } \\
\text { Mengalisis makna tersurat dengan gambar } \\
\text { Mengalisis makna tersirat dengan lembar kerja } \\
\text { proyek (Project Based Learning) }\end{array}$ \\
\hline $\begin{array}{l}\text { Prosedur } \\
\text { Aktivitas }\end{array}$ & $\begin{array}{l}\text { Peserta didik mengamati cuplikan film “Air Mata Ibu” } \\
\text { dan mengomentarinya } \\
\text { Peserta didik memahami makna mufradât dengan } \\
\text { menghafal ayat dalam QS. al-Kawthar [108] dan QS. } \\
\text { al-Mâ'ûn [107] } \\
\text { Peserta didik menganalisis makna kedua surat tentang } \\
\text { kondisi sosial di masyarakat secara berkelompok } \\
\text { Peserta didik mempresentasikan hasil kerja kelompok } \\
\text { Penguatan hasil belajar dari guru } \\
\text { Peserta didik mencari data kondisi anak yatim dan } \\
\text { fakir-miskin di desa masing-masing secara } \\
\text { berkelompok (tugas proyek di luar jam sekolah) }\end{array}$ \\
\hline \multicolumn{2}{|r|}{ Aktivitas Pembelajaran Pertemuan II } \\
\hline Strategi & Kegiatan \\
\hline Alpha Zone & $\begin{array}{l}\text { Salam pembuka } \\
\text { Mengecek kondisi peserta didik } \\
\text { Melakukan warmer (mengingatkan pelajaran yang lalu) } \\
\text { dengan curah pendapat }\end{array}$ \\
\hline Scene Setting & $\begin{array}{l}\text { Mencermati data statistik jumlah fakir miskin dan anak } \\
\text { terlantar di Jawa Timur melalui slide power point }\end{array}$ \\
\hline Metode & $\begin{array}{l}\text { Pengamatan } \\
\text { Presentasi proyek (hasil pencarian data kondisi anak } \\
\text { yatim dan fakir-miskin di desa masing-masing) }\end{array}$ \\
\hline $\begin{array}{l}\text { Prosedur } \\
\text { Aktivitas }\end{array}$ & $\begin{array}{l}\text { Peserta didik mengomentari jumlah fakir-miskin dan } \\
\text { anak terlantar di Jawa Timur yang masih tinggi } \\
\text { Peserta didik mempresentasikan proyek dari hasil } \\
\text { pencarian data jumlah fakir-miskin dan anak terlantar di } \\
\text { desa masing-masing dan solusi yang diberikan oleh para } \\
\text { tokoh masyarakat untuk mengentaskan mereka dari } \\
\text { kemiskinan dan keterbelakangan } \\
\text { Peserta didik secara berkelompok membuat rancangan } \\
\text { untuk kegiatan bakti sosial untuk mengurangi }\end{array}$ \\
\hline
\end{tabular}




\begin{tabular}{|l|l|}
\hline $\begin{array}{l}\text { kemiskinan dan keterbelakangan dalam rangka } \\
\text { mengamalkan nilai-nilai dalam QS. al-Kawthar [108] } \\
\text { dan QS. al-Mâ'ûn [107] } \\
\text { Penguatan hasil belajar dari guru }\end{array}$ \\
\hline
\end{tabular}

Sebagaimana yang tergambar dalam kegiatan pembelajaran di atas, Tahap pertama pada proses pembelajaran adalah apersepsi yang dimulai dengan Alpha zone. Fun story pada pertemuan pertama bernyanyi bersama "Sepohon Kayu" dan curah pendapat pada pertemuan kedua, mampu membuat semua peserta didik dalam suasana semangat dan gembira, sehingga gelombang otak benar-benar dalam kondisi alfa atau rileks.

Jill Ammon-Wexler menjelaskan bahwa otak bisa menghasilkan Endorphin; bahan biokima alami yang dapat membuat seseorang bersemangat. Endorphin dapat dihasilkan ketika kondisi gelombang otak berada pada gelombang Alpha, dan juga dapat meningkatkan kemampuan belajar dan daya ingat seseorang. Dengan kata lain, belajar dan mengingat akan lebih mudah dilakukan apabila terdapat cukup banyak Endorphin dalam otak. Apabila seseorang fokus pada konfigurasi gelombang otak alpha ini, ia akan lebih mudah untuk mengubah citra diri/gambaran mental negatif diri, menjadi citra diri/mental positif diri yang baru. ${ }^{26}$

Tahap kedua adalah scene setting dengan mengamati cuplikan film "Air Mata Ibu" pada pertemuan pertama, dan mencermati data statistik jumlah fakir miskin dan anak terlantar di Jawa Timur pada pertemuan kedua. Tujuannya untuk pemberian pengalaman belajar sebelum masuk ke substansi materi akan membangun konsep pembelajaran yang akan diberikan dan memantik penasaran peserta didik, sekaligus sebagai pereduksi perintah aktivitas setelahnya. Aktivitas ini adalah masih dalam gelombang alpha, di mana otak dalam keadaan rileks tetapi waspada dan konsentrasi. ${ }^{27}$

Tahap ketiga, peserta didik secara keseluruhan terlibat pada kegiatan belajar, aktivitas menghafal QS. al-Kawthar [108] dan QS. al-Mâ'ûn [107], diskusi menganalisis makna dalam ayat-ayat kedua surat, mencari data kondisi anak yatim dan fakir-miskin di desa masing-masing merupakan kerja otak masuk pada gelombang beta; kondisi sadar, melakukan aktivitas sehari-hari yang berkonsentrasi tinggi, melakukan

\footnotetext{
${ }^{26}$ Albrecht, The Power Minds at Work, 89.

${ }^{27}$ Ibid., 90.
} 
debat, atau melakukan proyek yang rumit. ${ }^{28}$ Sedangkan waktu menyusun hasil kerja kelompok, menyusun tulisan ilmiah, menyusun rencana bakti sosial, hingga mempresentasikan hasil kerja, adalah merupakan kerja otak dalam gelombang theta; keadaan sangat rileks, kondisi meditatif, ide-ide kreatif muncul. ${ }^{29}$

Tahap keempat, dalam melaksanakan proses pembelajaran mulai dari pertemuan pertama hingga pertemuan kedua, dengan aktivitas pengamatan, menghafal mufradât dan ayat-ayat QS. al-Kawthar [108] dan QS. al-Mâ'ûn [107], mencari sebab-akibat, menyusun hasil kerja secara kelompok/individu, dan presentasi, membuat setiap peserta didik mampu menggunakan semua fungsi otak kiri dan otak kanan, bahkan mampu menggunakan seluruh potensinya baik fisik maupun psikis (pikiran, perasaan, emosi, kesadaran, dan ingatan). Hal ini sesuai dengan konsep holistic activities dengan menggunakan kesadaran, tubuh, perasaan, pikiran, dan ingatan. ${ }^{30}$ Proses pembelajaran yang mampu mengerahkan keseluruhan potensi peserta didik ini, hasil pemahaman yang didapat akan mampu di-download oleh gelombang otak delta pada waktu tidur, dan disimpan dalam ingatan yang kuat (otak bawah sadar/long term memory). Karena pada hakikatnya otak manusia itu tidak pernah berhenti bekerja, selama masih ada kehidupan dalam diri manusia itu, tubuh bisa beristirahat pada waktu tidur, akan tetapi otak bekerja menyimpan seluruh informasi yang telah diterima melalui pancaindra. $^{31}$

Agar setiap peserta didik mampu menggunakan seluruh potensinya secara maksimal, maka pengelolaan arus informasi sampai dikelola oleh otak adalah sangat penting. Informasi tersebut akan melewati tiga stasiun yang mempunyai karakteristik berbeda.

Stasiun pertama, informasi yang didapat dari indera pada waktu pembelajaran akan melewati batang otak yang disebut otak reptil. Otak reptil ini menguasai dunia fisik. Artinya kalau informasi yang masuk dalam otak dan lingkungan memuaskan otak reptil, maka informasi tersebut akan diterima dengan baik. ${ }^{32}$ Dalam pembelajaran, pemuasan terhadap otak reptil adalah dengan menciptakan lingkungan kelas yang nyaman, sehat, dan indah, di mana kelas dibersihkan setiap hari, dinding dicat warna cerah, dan hiasan dinding dipajang rapi.

${ }^{28}$ Ibid., 91.

${ }^{29}$ Ibid., 93.

30 Jensen, Brain Based Learning, 219.

31 Albrecht, The Power Minds at Work, 129.

32 Gardner, Development and Education, 87. 
Selain itu, tempat belajar dengan udara yang bersih dan cahaya cukup sangat membantu memuaskan otak reptil. Peserta didik dapat menghirup udara segar dan merasa nyaman, tentu otak reptilnya akan tersenyum dan meloloskan semua informasi menuju ke stasiun kedua.

Setelah informasi tersebut memuaskan otak reptil, maka diteruskan ke stasiun kedua, yaitu otak limbic atau mamalia. Otak limbic ini menguasai dunia emosi. Artinya, peserta didik sebagai penerima informasi harus mempunyai kondisi emosi yang stabil, tidak dalam kondisi stres, tertekan, dan tegang. Kondisi emosi peserta didik harus positif, maka otak mamalia akan terpuaskan. ${ }^{33}$ Misalnya, sekolah menghimbau kepada para orang tua untuk mengkondisikan dan memastikan bahwa anak berangkat sekolah harus dalam keadaan siap, sebagai pelajar berangkat pagi ke sekolah dengan ceria, dapat dukungan dari orang tua, tugas sekolah sudah dikerjakan, di sekolah disambut guru-guru yang ramah. Dengan begitu peserta didik mengikuti pelajaran di kelas, biasanya lancar.

Setelah lolos dari otak limbic, maka informasi akan masuk ke stasiun ketiga yang disebut neo-cortex. Neo-cortex ini adalah sang pemikir. Artinya, sesulit apapun pelajaran yang diterima, apabila memuaskan otak reptil, dan memuaskan otak limbic, maka neo cortex akan mempunyai potensi yang besar untuk menganalisis pelajaran yang sulit. ${ }^{34}$ Semua peserta didik akan mampu mengikuti pelajaran dengan baik, dan bekerjasama dengan teman-teman sekelompoknya dengan saling melengkapi dan menghargai satu sama lain dengan berbagi tugas sesuai kemampuan masing-masing.

Proses pembelajaran dengan memperhatikan cara kerja otak, membuat para peserta didik mengeluarkan seluruh potensi dan bakat masing-masing, sehingga akan membantu mempercepat menemukan kecerdasan terbaiknya. Jika kecerdasan terbaik selalu diasah dalam setiap pembelajaran, maka profesi akan segera ditemukan, karena kecerdasan itu adalah proses discovering ability. ${ }^{35}$ Menemukan profesi (kondisi akhir terbaik) tidak harus menunggu usia dewasa/tua, namun akan lebih baik ditemukan saat usia muda.

Pembelajaran dengan menggunakan cara kerja otak ini, sejalan dengan konsep pendidikan Islam, bahwa manusia diciptakan oleh

\footnotetext{
33 Ibid., 89.

${ }^{34}$ Ibid., 91.

35 Howard Gardner, Multiple Intelligences: The Theory in Practice (New York: Basic Books, 1993), 193.
} 
Allah paling sempurna di antara makhluk lain, adalah karena manusia diberi otak. Otak adalah sumber kekuatan yang sangat dahsyat jika dimaksimalisir penggunaannya.

Dari paparan proses pembelajaran berbasis cara kerja otak suatu hal yang sangat esensial dalam proses pembelajaran yaitu di kegiatan akhir. Di kegiatan akhir sebelum pembelajaran usai, kemampuan guru dalam memberikan penguatan psikologis yang ditekankan pada penumbuhan kecerdasan spiritual (Islamic Character Building) sebagai tujuan utama yang harus dicapai pada setiap pembelajaran. Misalnya dengan menunjukkan manfaat dari materi yang telah dipelajari bagi eksistensi diri sebagai manusia, manfaat bagi orang lain, dan manfaat bagi lingkungan sekitar, dan mengaitkannya dengan ayat-ayat qauliyah (al-Qur'ân/Hadîth) atau ayat-ayat kawnîyah (bukti-bukti empiris) akan sangat efektif untuk menumbuhsuburkan spiritualitas peserta didik sebagai hamba dan khalifah Allah.

Dengan demikian, pembelajaran berbasis cara kerja otak mampu menghantarkan peserta didik menemukan eksistensi dirinya sebagai manusia hamba Allah yang berkompeten, bermanfaat, dan bermoral tinggi.

\section{Penutup}

Proses pengelolaan pembelajaran yang sesuai dengan cara kerja otak bertujuan agar peserta didik tertarik, berhasil dalam belajar dalam waktu yang relatif cepat, informasi/ilmu yang diperoleh dapat menggugah kesadaran dan tersimpan dalam ingatan yang kokoh.

Untuk mengoptimalkan pencapaian hasil belajar sebagaimana yang diharapkan dalam pendidikan Islam-selain melalui tahapan di atas-perlu diperhatikan cara kerja otak dari komponen, antara lain: pertama, Otak Reptil (Sang Penjaga) yang berfungsi sebagai pengatur fungsi denyut jantung dan pernapasan, melindungi dari bahaya fisik dengan pendekatan "lari atau lawan", dan mengendalikan dunia fisik, kedua, Otak Limbik (Sang Pengatur) yang berfungsi mengatur sistem kekebalan tubuh, hormon, tidur, kebutuhan keluarga, strata sosial, rasa memiliki, dan mengendalikan dunia emosional dan memori jangka panjang, dan ketiga Neo-Cortex (Sang Pemikir) yang berfungsi bekerja dengan logika, menanggapi dengan pikiran yang beralasan, dan mengendalikan dunia kreatif.

Energi informasi bergerak dari dasar otak (Otak Reptil) melalui pusat emosi (Otak Mamalia) terus ke bagian atas Neo-Cortex. Artinya, ketika anak didik telah siap untuk belajar, guru harus meyakinkan 
bahwa mereka merasa nyaman secara fisik, suhu udara, tata cahaya, dan area belajar harus memuaskan otak reptil. Setelah fisik anak didik merasa nyaman, guru harus memulai pembelajaran dengan sikap positif untuk memuaskan pusat emosi otak (otak limbik). Ketika dua bagian pertama otak sudah puas, maka otak pemikir (neo-cortex) dapat bekerja dengan baik.

Ketika ketiga fungsi otak telah bekerja dengan baik, maka guru harus membawanya/mengarahkan anak didik kepada eksistensi kemanusiaannya bahwa mereka adalah makhluk Allah, yakni apapun yang telah dipelajari akan dimanfaatkan untuk kehidupan pribadi dan sosialnya sebagai sarana mengabdi kepada Allah. Kecerdasan spiritual sebagai dasar dan tujuan utama setiap pendidikan/pembelajaran.

Strategi pembelajaran menggunakan cara kerja otak reptil, otak limbik, dan neo-cortex sebagai penggalian potensi anak didik yang akan menjadi profesi/kemampuan akhir terbaiknya, dan cerdas spiritual (God Spot) akan menjadi nafas hidup apapun profesi anak didik nanti.

\section{Daftar Rujukan}

Abrâshî (al), Muhammad 'Ațîyah. al-Tarbîyah al-Islâmîyah. Kairo: Dâr al-Ma'ârif, 1985.

Albrecht, Karl. The Power Minds at Work: Organizational Intelligence in Action. New York: Amacom, 2002.

Armstrong, Thomas. Multiple Intelligences in the Classroom. Alexandria, VA: Association for Supervision and Curriculum Development, 1992.

Brynie, Hickman. Brain Sense: The Science of the Senses and How We Process the World around Us. New York: Amacom, 2010.

Buzan, Tony. The Power of Creative Intelligence: $10 \mathrm{~W}$ ays to Tap into your Creative Genius. Thorsons: Harper Collins Publisher, 2001.

Chatib, Munif. Sekolahnya Manusia. Bandung: PT Mizan Pustaka, 2009.

Gardner, Howard. Development and Education of the Mind. New York: Basic Books, 1992.

-----. Multiple Intelligences: The Theory in Practice. New York: Basic Books, 1993.

Hall, L. Michael dan Bodenhamer, Bob G. The User's Manual for The Brain. British Library: Crown House Publishing Limited, 1999.

Jensen, Eric. Brain Based Learning: The New Paradigm of Teaching. California: Corwin Press, 2008. 
-----. Teaching with the Brain in Mind, $2^{\text {nd }}$ Edition. Virginia: Association for Supervision and Curriculum Development Alexandria, 2005.

McKenzie, Walter. Multiple Intelligences and Instructional Technology. Washington DC: International Society for Technology Education, 2005.

Pasiak, Taufik. Brain Management for Self Improvement. Bandung: Mizan, 2007.

Revolusi IQ/EQ/SQ Antara Neurosains dan Al Qur'an. Bandung: Mizan Pustaka, 2004.

Qardhawi, Yusuf. Al-Qur'an Bicara tentang Akal dan Ilmu Pengetabuan. Jakarta: Gema Insani Press, 1998.

Zohar, Danah dan Marshall, Ian. Project SQ: Spiritual Intelligence the Ultimate Intelligence. London: Bloomsbury Publishing, 2000. 